\title{
The Ethics of Deontology in Corporate Communication
}

\author{
Francis E.A. Owakah \\ Department of Philosophy and Religious Studies \\ University of Nairobi, Kenya \\ fowakah@yahoo.com \\ and \\ Daniel Robert Aswani \\ Department of Immigration \\ Nairobi, Kenya \\ ranaswa@yahoo.com
}

Thought and Practice: A Journal of the Philosophical Association of Kenya (PAK) New Series, Vol.3 No.1, June 2011, pp.115-129

thoughtandpractice@gmail.com

http://ajol.info/index.php/tp/index

\begin{abstract}
This paper seeks to provide guidelines on how to respond to the ethical challenges entailed in corporate communication. It argues for the need for an ethical grounding for the practitioner of corporate communication, before critically examining the two broad ethical theories - deontology and teleology - and their place in ethical judgment. The authors underscore the importance of deontological ethics in the practice of corporate communication.
\end{abstract}

Key Words. Corporate communication, public relations, ethics, deontology, teleology

\section{Introduction}

Corporate Communication is the set of activities involved in managing, ordering and orchestrating all internal and external sharing of information with stakeholders on whom an organisation depends and with whom it relates. The messages could target 
an internal public as well as an external one. The internal public includes employees and shareholders. The external public includes the general public, institutions that provide services to the organisation, that may include the media, government, industries and educational institutions. The messages to be communicated are generated by a variety of specialists and non-specialists within the Organisation, with the aim of enhancing the Organisation's ability to achieve its stated operational mandate. This means that corporate communication helps Organisations explain their vision, mission and core values to all the stakeholders. However, for an organisation to achieve its objectives, it is crucial that it communicates to all its stakeholders coherently, credibly and ethically. This implies the need for a very specialized methodology and theoretical underpinning within the wider meaning of communication.

Furthermore, corporate communication engages an Organisation with its stakeholders in a manner that benefits both the Organisation and the stakeholders. Such interaction ought to be guided by ethical principles, so that one party does not benefit at the expense of the other. However, quite frequently, when corporate communicators conduct their business, they often downplay, or fail to recognise, the importance of ethics. Yet in the course of duty, the corporate communicator is bound to encounter different scenarios, at times dilemmas, that require ethical consideration and judgment. It is therefore imperative that such a practitioner be equipped with sufficient ethical knowledge, so that he or she can make informed ethical decisions.

Consequently, in this paper, we argue for the place of ethics in corporate communication, with specific reference to deontological ethics. The paper first discusses the concepts of public relations and corporate communication, before undertaking reflection on teleological and deontological ethics. It then advances an apologia for deontological ethics. The penultimate section deals with the place of ethics in codes of conduct. Finally, we present conclusions and recommendations for the practice of corporate communication. 


\section{Public Relations or Corporate Communication?}

Communication is the sharing of information between two or more persons. When one communicates, one disseminates information that was initially confined to him or her. Communication has also been defined as the process of imparting facts, information and ideas (Sagimo 2002). The purpose of sharing this information is to promote understanding between the parties involved. It is in this regard that Smith (1992) affirmed that communication is "creating understanding." Communication is a process that involves a sender encoding a message before using an appropriate channel/medium to relay it to a designated receiver. The receiver has to decode the message and provide feedback.

Over time, the discipline of communication has grown in leaps and bounds to produce sub disciplines such as human communication, corporate communication, development communication and media studies. Whereas this paper may make reference to some of the other areas of specialization, its focus is corporate communication.

At its inception, corporate communication was generally seen to be akin to public relations, where the latter is simply the "establishment and maintenance of mutually beneficial relationships" (Jefkins 1998). In the practice of public relations, an Organisation recognizes the role played by strategic stakeholders (publics), and relates well with them for the mutual benefit of the Organisation and the public. Tench and Yeomans $(2006$, 4) have defined public relations as a distinctive management function which helps establish and maintain mutual lines of communication, understanding, acceptance and cooperation between an Organisation and its publics; involves management of problems or issues; helps management to keep informed on and responsive to public opinion; defines and emphasizes the responsibility of management to serve the public interest; helps management keep abreast of and effectively utilize change; serves as an early warning signing system to help anticipate trends; uses research and ethical communication techniques as its principal tools. 
The last definition above captures the essence of the practice of public relations, and hints at the current discourse on the relationship between public relations and corporate communication. Today, the role of public relations officers is performed by corporate communicators, with the former being re-designated as corporate communication managers. A healthy debate exists in the attempt to explain what these two roles entail and imply in an Organisational context. For ease of understanding, we shall use image versus structure to refer to the proponents of public relations and corporate communication theorists respectively.

Image theorists hold that at its inception, the practice of public relations did not have adequate structures that could enable the training of personnel to take up tasks reserved for public relations officers. As a result, trained journalists moved from their mainstream profession to fill this gap. In the course of duty, these journalists encountered several nasty experiences with their former colleagues - those left practicing journalism. The journalists accused the public relations officers of hoarding the truth, acting unprofessionally including being spin doctors, and being ready to say anything for the sake of the Organisations they represented. This perceived shortcoming has followed the profession, and continually casts doubt on the capacity and moral integrity of public relations managers.

The foregoing clearly points to the fact that reputation managers had suffered a reputational crisis (Steyn and Puth 2000), and this created the need for concept and image changeover. Taken at this level, public relations and corporate communication are not essentially different, and can therefore be used interchangeably (Jefkins 1998; Oliver 2007).

Structure theory is perhaps best illustrated in the writing of Cornelissen (2000), who holds the opinion that for a long time, the practice of public relations was more of a technical rather than a managerial duty. To support this claim, he observes that in most cases, public relations practitioners reported to the marketing section rather than to the chief executive of the Organisation. This was done without regard to the difference between corporate marketing and product marketing. However, this 
situation is slowly changing with the realization of the enormous tasks undertaken by corporate communicators.

Today, corporate communicators occupy managerial positions, and report directly to the chief executive. It is this scheme of conceptualization that allows Cornelissen $(2000,23)$ to define corporate communication as "a management function that offers a framework and vocabulary for the effective coordination of all means of communications with the overall purpose of establishing and maintaining favorable reputations with stakeholders and groups upon which the Organisation is dependant." Defenders of the structure theory hold that the terms public relations and corporate communication belong to two different epochs, and are thus functionally different, so that the use of one does not imply the other.

Whereas here we are concerned with corporate communication as opposed to public relations, we are more inclined to the image rather than the structure theory because contemporary public relations managers perform duties similar to those advanced by structure theorists.

In corporate communication, 'publics' are groups that have a direct or indirect association with an Organisation, and who affect or are affected by its operations. Publics (or stakeholders) can be internal audiences, external audiences (Lesikar and Pettit 2006) or media. Internal audiences include shareholders (owners), employees (top managers, middle managers, supervisors, technical and subordinate staff), and trade unions. External audiences include suppliers, creditors, competitors, and the political establishment, to mention but a few. In our view, although the media (print, electronic etc.) could easily be classified as part of the external public, they constitute a third force in stakeholder management. In their quest to inform their audiences, the media develop interest in matters within an Organisation, making them a strategic partner in the endeavour to create the desired Organisational image. The bottom-line is that relations between an Organisation and its publics have to be determined by principles that guide human relations, thus the relevance of ethics.

Every corporate communicator has to cut his or her niche in accordance with the Organisational goals which have traditionally been to reduce risk, maximize profits 
and cut costs (Argenti 1998). Relating well with the publics is fundamental to the attainment of these goals. In many Organisations, the management of the reputation of the entity is the province of the corporate communicator. Reputation management starts with the projection of the Organisation to the publics. This projection becomes the reference point for the stakeholders each time they encounter and interact with the Organisation. For instance, where the Organisation operates under the slogan "service to humanity", the publics want to see if every action of the Organisation is geared towards this call.

In the course of interaction, the public forms an image of the Organisation, which when observed over time and an aggregate picture of the Organisation from the public's eyes is developed, becomes the Organisation's reputation (Steyn and Puth 2000). Corporate reputation is thus an attribute inferred from an Organisation's past actions. A good reputation is based on proper relationship and image management.

The corporate communicator is often described as a boundary spanner, implying that he or she must have one leg in the Organisation and the other among the publics. He or she identifies the needs, interests and concerns of each stakeholder, which he then uses to segment the various audiences. Further, the corporate communicator has to represent the various interests of the publics to the Organisation, and at the same time carry the Organisation's message to the publics through lobbying, advocacy, community relations and corporate citizenship. Seen from this perspective, the function of a corporate communicator is necessary in strategy formulation and implementation. As Oliver (2007) observes, after strategy formulation, it is the corporate communicator who disseminates the Organisational strategy intent to the stakeholders. This can be done through posters, speeches, annual reports, intranet, oped articles and press releases, among others. For the corporate communicator to effectively pass on such information, he or she must have writing, editing, presentation, public speaking, listening and people skills (Foster 2005; Smith 1992).

The corporate communicator has at his or her disposal at least three models through which he or she can pass on information about the Organisation's strategy, namely, press releases, public information and two-way asymmetrical models. Of all these, 
only the two-way symmetrical model appropriates the views of the publics in the development of Organisational positions. Although this model is widely accepted because it considers the interests of the audience alongside those of the Organisation, it is our position that a more important ground for its desirability is that it espouses the ethical notion of treating others as ends and not as means to some end.

\section{The Need for Moral Reasoning on Corporate Communication}

In the course of interacting with the various publics, corporate communicators handle issues relating to libel, truth, sensationalism, hyperbolism and intellectual property rights (Grunig \& Hunt 1984). Other concerns include source credibility, respect for the audience, equity and social responsibility (Lieber 2001), as well as espionage (Bowen 2007). The decisions they make in such circumstances often have moral implications, since they entail choices between or among competing loyalties and values (Frankena 2001; Heath 2005, 205-206). Thus corporate communicators are expected to forecast the moral implications of making a decision to pass across a particular message. This calls for grounding in moral philosophy. Traditionally, moral philosophy, also referred to as "ethics", undertakes reflection on principles by which to determine what ought to be done and what ought not to be done.

In our view, the right decision ought to be based on moral principles, and this is what makes such decisions explicable to the public. Let us consider some of the practical moral scenarios that confront the corporate communicator:

- What does a corporate communicator do when he or she establishes that the reason why a firm for which he or she works has a dwindling reputation is that the products it sells are suspected to be causing deaths? Does he or she have a duty to inform the public in equal measure with the chief executive of the Organisation?

- A company has been emitting carbon monoxide within the environment of the host community, adversely affecting the people's health. The community has petitioned the company and the government. The matter is threatening to spill into the media. The government seeks a comprehensive statement from the company. Is the corporate communicator morally obliged to tell the truth at the expense of the company's image? 
- Should a corporate communications manager in a reputable airline conceal information from desperate family members about the death of their loved ones in an air crash just to buy time for the CEO to consult the Board and the airline insurer?

While the scenarios above might seem like pen and paper issues, they are loaded with ethical considerations and implications. The question is, what considerations ought to guide the corporate communicator as he or she deals with such issues?

\section{Two Moral Options: Teleological versus Deontological Principles}

Moral reasoning is characterised by two broad perspectives. On the one hand, there is the view that an action is right because it brings forth some desirable results and wrong if the consequences are not beneficial. This is the ethics of teleology, also referred to as consequentialist morality (McNaughton and Rawling 2006; Frankena 2001). In this case, the corporate communicator will consider whether or not a decision is likely to produce the best possible results from the available alternatives. However, the corporate communicator may be guided by selfish interests - those that favour him or her, or the organisation for which he or she works..

Besides, with regard to consequentialism, the challenge for the corporate communicator is the ability to be prophetic. How, for instance, would a corporate communicator know the consequences to anticipate when he or she gives a statement to the media to the effect that the company is downsizing? Suppose one communicator anticipates a series of desirable consequences and agrees to an action, whilst another refrains from the action because of anticipated undesirable outcomes, shall we not be courting Protagoras' man as the measure of all things? Such a position may reduce corporate communicators to the absurdity that is relativism - that what is true for me need not necessarily be true for you. Logicians point out that relativism collapses when one affirms what one seeks to deny (Copi and Cohen 1998), or that truth is as multifaceted as the number of perceivers of it. Relativism ends up stultifying the corporate communicator, since he or she would be forced to deny the absolute, and do so absolutely (Geisler 1976). 
Deontological theorists, on the other hand, concentrate on an action itself, rather than on its consequences. Borchert $(2006,713)$ defines deontology as "the ethical theory, or family of ethical theories, according to which there are constraints on promoting overall best consequences that imply that sometimes the right act is not the one whose consequences are best." Deontologists hold that an action is right because it intrinsically carries the imperative to act in such a manner. The action places on a moral agent a duty which cannot be avoided. Deontologists assert that an action in and of itself has intrinsic characteristics that make it right or wrong. Thus for deontologists, in a specific situation, any rational agent would choose the same course of action.

The deontological view was memorably articulated in the Kantian Categorical Imperative, which is summed up as: in everything we do it must be from the maxim that is general in purpose, and that this maxim ought to be one that we could will to be applied to everyone in similar situations. It is a maxim that applies without exception. For example, if a corporate communicator plans to lie to defend the Organisation, he or she should will that every other person in similar circumstances tells lies. If this is not the desire of the practitioner, then lying is wrong; but if lying is right for $\mathrm{A}$, it cannot be wrong for B. what is more, Kantian morality forbids the treatment of humanity as means to some personally designed and desired end. According to Kant, we ought not to treat human beings as instruments to achieve our goals. Corporate communicators must therefore treat the public as ends in themselves, and not means to profit and corporate glory.

Thus corporate communicators would benefit from the deontological approach to moral issues. Borchert (2006), Heath (2008) and McNaughton and Rawling (2006) discuss constraint, duties of special relations, and options as crucial considerations in deontology. Under the guidance of deontology, corporate communicators would be constrained, given the prohibitions that limit their operations. Among other constraints, they are to refrain from telling lies, advancing ghost writing or employing propaganda. The duty to special relations arises from the fact that we all have ties to which we are obligated. For instance, when I promise, I have a duty to keep the promise. This would be a threshold on the part of the communicator, since everyone 
would be interested to know whether he or she (the communicator) can be taken at his or her word. The deontological rubric of option arises from the inadequacy of teleological theories. Duty demands that moral agents engage in acts of philanthropy, but within certain limits. The rubric guides the communicator into which philanthropic acts the organisation ought to engage in as a corporate citizen, but also indicates to him or her the extent of the engagement.

\section{Apologia for Deontological Morality in Corporate Communication}

In the preceding sections, we have sought to make a case for deontological morality, and to debunk the myth that consequences determine the morality of an action. Going by teleology, corporate communicators would have to choose one of the optional actions by calculating which of them is likely to produce the highest good - a relativistic endeavour which entails the well known conceptual difficulty that relativism itself relies on the absolute standard that "Everything is relative".

Deontological morality seems to cushion the corporate communicator in terms of the three rubrics discussed above, viz. constraints, special relations and options. The function of the corporate communicator entails relation building and management. This being the case, the communicator has a duty to respect the loyalty of the publics. If he or she betrays this loyalty, the publics have a right to lodge a moral complaint (McNaughton and Rawling 2008, 442). The converse is also true - where the publics betray the loyalty of the corporate communicator. In our opinion, the function of corporate communication would be made more effective by the constraining aspect of deontology, which would provide moral orientation to the practitioner before he or she gives advice to management. When a communicator presents a moral constraint, no one needs to calculate the consequences. Instead, the basis of action can be explained in the light of plausible theories. An Organisation is bound to extend its frontiers in each strategic period. The launch into the foreseeable future may be guided aptly by reference to deontological morality than by calculating the consequences of actions. 
Furthermore, it is crucial that the corporate communicator be beyond reproach. This is due to the fact that the line between his or her personal life and the Organisation's life is very thin. Corporate communicators must carry themselves with decorum because any negative image attributable to them adversely affects the Organisations for which they work. In deontological reasoning, desirable character traits are identified through the use of concepts such as dignity, respect, good intention and duty, which corporate communicators can be required to exemplify.

\section{Codes of Conduct}

Today, ethical discourse in public relations is enshrined in codes of conduct. According to Health $(2005,138)$, such a code entails "a formal statement of conduct or a set of rules, standards, or guidelines for appropriate member behavior that has been adopted by an Organisation or professional association." The code specifically states what ought to be done by those it binds, and similarly offers general ethical guidelines for operations.

In the codes of conduct, a practitioner will find guidelines on loyalty and obligations. Historically, codes of conduct emerged because of the ethical blunders that bedeviled companies and professions in the 1950s, although the origin of codes of conduct goes further than the professional pandemonium in the 1950s. For example, the Hippocratic Oath, administered to medical doctors to guide their conduct, has its origins in ancient Greece. Today, codes of conduct are enshrined in Organisations' strategic formulations, and often are based on the mission, vision and core values of the Organisation. In a nutshell, these constitute the guidelines of professional conduct.

The corporate communicator is bound by the Organisation's code of conduct, and has the secondary role of ensuring that the code is communicated to the internal public, and explained to external publics should this benecessary. Heath (2005) outlines the benefits that accrue to professionals from observance of a given code of conduct. These include, but are not limited to:

- Protecting the Organisation from legal liability.

- Constraining and guiding employee behavior.

- Minimising unethical conduct. 
- Assisting in communicating value positions.

- Enhancing the image and reputation of the Organisation.

In the event that an action requires scrutiny by the various publics, the code of conduct is the criterion by which they will evaluate it. The field of communication has had codes guiding journalists, development communicators, and corporate communicators, among others. However, the problem with the professional code of conduct for corporate communicators is that it is not as binding to the communicator as the Organisational one is. One communicator might join a professional body and ascribe to its code, but at his or her place of work, the Organisation's code becomes the final reference. Consequently, there is need for tighter rules to ensure compliance with the corporate communication professional ethics encapsulated in the relevant code of conduct.

\section{Conclusion}

What is the implication of the foregoing discussion on the work of the corporate communicator? Like any other manager, the corporate communicator has a number of tasks, among the traditional ones being planning, organizing, integrating and measuring (Drunker 1993, 393-394). Additionally, the corporate communicator has to contend with language and linguistic tools and variables, technology and the environment, social Organisation, contextualizing and face-saving, concepts of authority, body-language and non-verbal communication, and concepts of time (Goodman 1994, 2). These tasks imply that the corporate communicator cannot avoid making decisions, among which are moral ones. In every situation, a corporate communicator is faced with at least five issues: definition of the situation, values involved, principles upholding the values, loyalties and judgment (Christians, Rotzoll and McKee 2005).

A definition of the situation will give the corporate communicator an opportunity to understand the environment in which he or she operates. Values have to do with the communicator's ideas of right and wrong. The values will be grounded on a competent theoretical framework articulated by principles. Loyalties represent the 
relationships between or among the parties involved in the situation. All these factors equip a corporate communicator to make sound moral judgments. Figure 1 below illustrates our point.

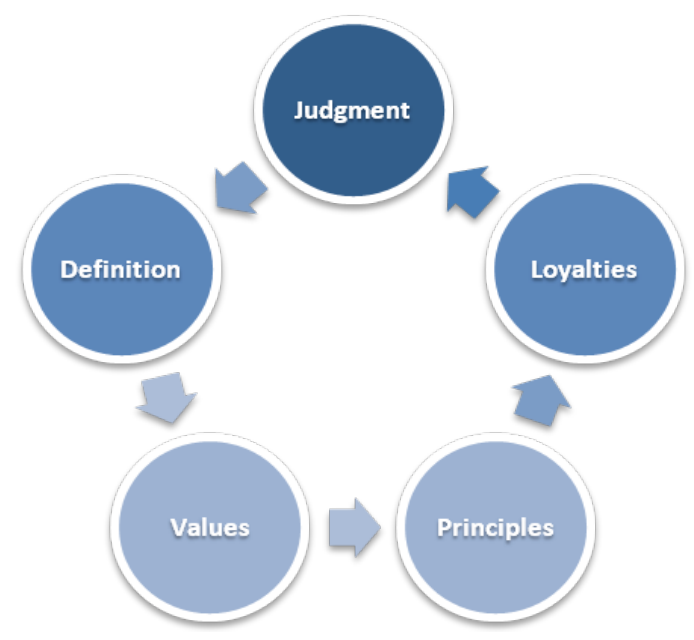

Fig. 1. Cycle of Moral Judgment

One way of grounding corporate communicators in moral theory is to make the study of ethics a mandatory course in their education. With the discipline churning out potential practitioners each year, it is important that they are grounded in the principles of moral reasoning. Furthermore, corporate communicators study and advise on Organisational culture. Organisational culture implies that some values are acceptable, and these should be made manifest in the conduct of the employees and management. A corporate communicator ought to play an important role in the assessment of such values on the basis of sound ethical reasoning.

According to Bowen (2006), management ought to engage corporate communicators as issue managers, since they can anticipate and handle issues before they degenerate into crises. Brønn and Brønn (2002) argue that the more ethical issues are raised and addressed in an organisation, the more strategic it remains. These considerations are relevant to the communicators, since they play a crucial role in the formulation of an Organisation's strategy.

An acquaintance with moral philosophy is likely to positively influence the actions of corporate communicators when they are confronted by moral dilemmas. Before corporate communicators arrive at decisions, they need to thoughtfully consider the 
logical and ethical implications on a case by case basis. Thus corporate communicators ought to apprehend situations in minute details. Following René Descartes, we recommend that the following be incorporated into a future curriculum for the education of corporate communicators, as well as in their professional code of conduct:

1. Never accept any claim as true unless it is clear and distinct. As much as possible corporate communicators should avoid prejudgment. They should instead be guided, through systematic doubt, to a conclusion that is evident and certain.

2. Never handle a complex issue as though it were a simple problem. Corporate communicators should analyse complex issues into their component parts in order to identify appropriate solutions to them. They must always remember that understanding a question is part of the answer to it.

3. Always adopt a logical model in thinking. Thinking effectively involves contemplating things that are simple, as opposed to those that are complex.

Equipped with the three guidelines above, corporate communicators will find moral reasoning to be instrumental in their practice. They will argue from first principles and not to them.

\section{References}

Argenti, Paul A. 1998. Corporate Communication. Boston: McGraw-Hill.

Borchert, Donald M. 2006. Encyclopedia of Philosophy, $2^{\text {nd }}$ ed.. New York: Thomas Gale.

Bowen, Shannon A. 2007. "Ethics and Public Relations". http://www.instituteforpr.or/topics/ethics-and-public-relations

Brønn, Peggy B. and Carl Brønn. 2002. "Issues Management as a Basis for Strategic Orientation". Journal of Public Affairs, Vol.2 No.4, pp.247-258. http://www3.interscience.wiley.com

Christians, Mark Fackler, Kim B. Rotzoll, and Kathy B. McKee. 2005. Media Ethics: Cases and Moral Reasoning. Boston: Pearson Educational Inc.

Copi, Irving and Carl Cohen. 1998. Introduction to Logic. London: Prentice Hall. 
Cornelissen, Joep P. 2005. Corporate Communications: Theory and Practice. London: Sage Publications.

Cutlip, Scott M., Allen H. Center and Glen M. Broom. 1994. Effective Public Relations, 7th Ed. New Jersey: Prentice-Hall.

Drunker, Peter F. 1993. Management: Task, Responsibilities, Practices. New York: Harper Business.

Frankena, William. 2001. Ethics. New Delhi: Prentice Hall Inc.

Foster, John. 2005. Effective Writing Skills for Public Relations, 3rd Ed. London: Kogan Page Ltd.

Heath, Robert. 2008. Following the Rules: Practical Reason and Deontic Constraint. New York: Oxford University Press.

Heath, Robert L. ed. 2005. Encyclopaedia of Public Relations, Vol.2. London: Sage Publications, Ltd.

Geisler, Norman. 1976. Christian Apologetics. Grand Rapids: Baker Book House.

Grunig, James E. and Todd T. Hunt. 1984. Managing Public Relations. New York: Holt, Rinehart and Winston.

Goodman, Michael. B. 1994. Corporate Communication: Theory and Practice. Albany: State University of New York Press.

Jefkins, Frank. 1998. Public Relations. London: Prentice Hall.

Lesikar, Raymond V. and John D. Pettit. 2006. Business Communication: Theory and Application. New Delhi: A.I.T.B.S.

Lieber, Paul S. 2003. "Ethics in Public Relations: Gauging Ethical Decision-making Patterns of Public Relations Practitioners". Masters Thesis, Syracuse University.

McNaughton, David and Piers Rawling. 2006. "Deontology”. David Copp ed. Oxford Handbook on Ethical Theory. New York: Oxford University Press, Pp.424-458.

Oliver, Sandra. 2007. Public Relations Strategy, 2nd ed. London: Kogan Page.

Sagimo, Peter O. 2002. Management Dynamics. Nairobi: East African Educational Publishers.

Smith, Donald K. 1992. Creating Understanding: A Handbook for Christian Communication across Cultural Landscapes. Michigan: Zondervan Publishing House. Tench, Ralph and Liz Yeomans. 2006. Exploring Public Relations. Essex: Pearson Education Limited. 